\title{
Solana and his Civil Servants: An Overview of Political-Administrative Relations
}

Citation for published version (APA):

Dijkstra, H. (2011). Solana and his Civil Servants: An Overview of Political-Administrative Relations. In G. Mueller-Brandeck-Bocquet, \& C. Rueger (Eds.), The High Representative for the EU Foreign and Security Policy: Review and Prospects (pp. 65-85). Nomos.

Document status and date:

Published: 01/01/2011

Document Version:

Early version submitted to journal

Document license:

Unspecified

\section{Please check the document version of this publication:}

- A submitted manuscript is the version of the article upon submission and before peer-review. There can be important differences between the submitted version and the official published version of record.

People interested in the research are advised to contact the author for the final version of the publication, or visit the DOI to the publisher's website.

- The final author version and the galley proof are versions of the publication after peer review.

- The final published version features the final layout of the paper including the volume, issue and page numbers.

Link to publication

\footnotetext{
General rights rights.

- You may freely distribute the URL identifying the publication in the public portal. please follow below link for the End User Agreement:

www.umlib.nl/taverne-license

Take down policy

If you believe that this document breaches copyright please contact us at:

repository@maastrichtuniversity.nl

providing details and we will investigate your claim.
}

Copyright and moral rights for the publications made accessible in the public portal are retained by the authors and/or other copyright owners and it is a condition of accessing publications that users recognise and abide by the legal requirements associated with these

- Users may download and print one copy of any publication from the public portal for the purpose of private study or research.

- You may not further distribute the material or use it for any profit-making activity or commercial gain

If the publication is distributed under the terms of Article $25 \mathrm{fa}$ of the Dutch Copyright Act, indicated by the "Taverne" license above, 


\title{
Solana and his Civil Servants: An Overview of Political-Administrative Relations*
}

\author{
Hylke Dijkstra
}

\begin{abstract}
2011
This is a pre-print of a chapter whose definite form has been published in: Gisela Müller-Brandeck-Bocquet and Carolin Rüger (eds) (2011)

The High Representative for the EU Foreign and Security Policy: Review and Prospects, Baden-Baden: NOMOS Verlag.
\end{abstract}

\begin{abstract}
Despite their importance in the study of public administration, politicaladministrative relations between Javier Solana and his civil servants have received little attention in the scholarly literature. This is unfortunate, because they tell us something about the distribution of power within the Council Secretariat, the accountability of his civil servants, and the sort of organisation that Solana leaves behind. This chapter gives a first overview of political-administrative relations and it makes two observations. First, the relations between Solana and his civil servants were atypical in terms of political-administrative relations. The position of the High Representative was not quintessentially political and the Council Secretariat was not a traditional bureaucracy. Second, when looking at the everyday relations between Solana and his civil servants, this chapter notes that while Solana preferred to focus on the 'big picture' in order to establish his political office, he also often had to deal with the practicalities of policy-making. Furthermore, his contacts with civil servants were limited and based on pragmatic informal relations rather than the formal hierarchical lines of the bureaucracy. This chapter finally notes that Solana spent little political capital vis-à-vis the member states on the development of his own organisation. In conclusion, this chapter looks at the Lisbon Treaty and analyses what it means for political-administrative relations.
\end{abstract}

* This chapter is based on (often anecdotal) impressions gained during some hundred semi-structured elite interviews with officials from the EU institutions and the member states conducted over the period 2006-2010. 


\section{Introduction}

One of the major achievements often credited to Javier Solana, the first High Representative for the EU's Common Foreign and Security Policy (CFSP), is the development of his supporting bureaucratic organisation (for example, Duke in this volume). When he was appointed in 1999, he had some seventy civil servants working for him. Ten years later when he left office, there were approximately 600700 civil servants in Brussels directly reporting to him. ${ }^{1}$ Through various ways and means, Solana thus managed to create a European foreign service of considerable size avant la lettre. These civil servants in the Council Secretariat, together with their counterparts in the European Commission services, will make up the bulk of the future European External Action Service (EEAS), which is foreseen under the Treaty of Lisbon. These bureaucratic developments in the Council Secretariat have caught scholarly attention and have been well-covered in the academic literature (e.g. Christiansen 2002; Dijkstra 2008, 2009, 2010; Duke in this volume; Vanhoonacker and Christiansen 2008; Grevi 2007; Spence 2006; Duke and Vanhoonacker 2006; Vanhoonacker, Dijkstra and Maurer 2010). What has received little scholarly attention, however, is the day-to-day relationship between Solana and his civil servants. ${ }^{2}$

Political-administrative relations are amongst the most important topics in the academic study of public administration (e.g. Wilson 1887; Weber 1922; Simon 1947; Waldo 1948). While the focal points in studying this relationship have shifted over time, the problem of the reconciliation between democracy and bureaucracy has remained persistent. The underlying idea when it comes to politicaladministrative relations is that while politicians have a democratic mandate, career civil servants do not. Yet in modern states decision-making and implementation have become so complex that politicians have to rely on civil servants for their expertise and administrative capacity. Such asymmetrical dependence, of course, comes at a cost. Through the use of "hidden information" and "hidden action", civil servants can affect the contents of policy-making in ways that are beneficial for them (Arrow 1985). Understanding the relations between Solana and his civil servants in the Council Secretariat will thus not only shed a light on the power relations within his organisation (who was calling the shots), and the sort of organisation that Solana leaves behind, but also on the accountability of these civil servants.

The first observation of this chapter is that the relations between Solana and his civil servants were atypical in terms of traditional political-administrative relations. Solana himself had, of course, a political background and profile, but the

1 The Policy Unit and the Directorate for External Relations were in place from the beginning of Solana's term-in-office, but they dramatically increased in size. The Crisis Management Planning Directorate (CMPD), the Military Staff (EUMS), the Civil Planning and Conduct Capability (CPCC), the Joint Situation Centre (SITCEN) and the offices of the Special and Personal Representatives were furthermore created over time.

2 This chapter is only concerned with the Common Foreign and Security Policy. It does not discuss the position of the Secretary-General of the Council or the first pillar civil servants in the Council Secretariat. 
position of the High Representative as defined in the Amsterdam Treaty was not quintessentially political (see also Regelsberger in this volume). As a result, Solana had to go to great length to establish his profile and the 'politicalness' of his office. Quite similarly, the civil servants in the Council Secretariat were neither standard bureaucrats. From the traditional Wilsonian perspective, "administration should not be driven by partisan patronage and electoral politics" (Rosenbloom 2008: 57), but it should instead be regarded as "a field of business" (Wilson 1887: 20). This means clear hierarchies, impersonal offices, civil servants with the same backgrounds and training, and career paths based on merit (Weber 1922). Yet the Council Secretariat in the Solana decade was anything but. There were continuously rotating seconded national officials, which made it very difficult for the Council Secretariat to focus on the long-term and to accumulate institutional memory. In addition, while there were no strictly personal offices, the Secretariat did contain some national fiefdoms and seats, instead of recruiting strictly on merit.

The second observation is that these ambiguities, both at the political and the administrative level, affected the everyday relations between Solana and his civil servants. In terms of the division of labour, Solana was keen to concentrate on the 'big picture', preferring to spend his time on things like the European Security Strategy (ESS) and the Middle-East Quartet in order to establish the political profile of the High Representative. He, however, did not leave everything to the bureaucratic level: Solana was also, due to the way the EU is structured, time and again involved in the micro-management of the plethora of crisis management operations around the globe. Because of his overloaded agenda, it is worth noting that Solana had very little contact with the lower level civil servants. Instead, he preferred to rely on a limited number of trustees within his organisation. Such informal relations were driven partially by his personal preference, but also the result of a structure with a lack of hierarchy and permanence in the Council Secretariat. Finally, it must also be noted that Solana spent little political capital $v i s-\grave{a}$-vis the member states in terms of organisational leadership. During the Solana decade, the Council Secretariat with all its reorganisations and with the late arrival of civilian structures was a bit of a mess. Most of this had to do with the member states, which were formally in charge of the organisation of the Secretariat, but Solana was also reluctant to confront them over the strategic development of his own bureaucracy.

The informal structures and personal networks between Solana and his civil servants (and amongst a number of civil servants themselves) undoubtedly had their advantages in terms of flexibility, pragmatism, and the ability to get the job done. This may have been what Solana valued most about his organisation. It is, in this respect, remarkable that Solana's closest aids were exactly the types of people capable of thinking outside the box in a flexible non-institutionalised manner, transcending the pillar structure, on which the European Union is based. However, now that Solana has left office, and with Baroness Ashton stepping in with her Commission-oriented allegiances, the structure that remains behind - Solana's organisational legacy - is not necessarily the best building block for the future. This chapter, however, starts by putting the political-administrative relations in a broader context, before it takes a look at these relations between Solana and his civil 
servants on a daily basis. It discusses Solana's activities, his day-to-day contacts with civil servants and his role in organisational development. In the conclusion, this chapter takes a look at the implications of the Treaty of Lisbon on the politicaladministrative relations.

\section{Political-Administrative Relations in a Context}

Political-administrative relations are one of the most important topics in the academic study of public administration. One strong tradition is, in this respect, that of the dichotomy between the political and the administrative level where both do not interfere in each others' affairs (Wilson 1887; Weber 1922). While it is common wisdom (today) that civil servants do affect decisions made by their politicians and that they engage in bureaucratic politics of their own, there still exists a strong normative belief that politicians have a democratic mandate and that civil servant should act as professionals accepting all directives from the top. It is, however, not always easy, as Hill (2003: 95) rightly notes with regard to political-administrative relations in the domain of foreign policy, to separate the dog from its tail. This is also the case in the relationship between Solana and his civil servants, where it is indeed extremely difficult to define and to distinguish between the political and administrative level. This section discusses the limits of the dichotomy in the case of Solana and his civil servants. Yet rather than to do away with this analytical framework, it is more useful to analyse the implications for their relations.

\subsection{Javier Solana: a non-elected politician on a bureaucratic seat}

Notwithstanding Javier Solana as a person, the position of the High Representative was by many standards not a typical political post. Firstly, the High Representative under the Amsterdam Treaty had a democratic mandate next to none. It was not an elected office nor was the appointment procedure subject to hearings and a formal confirmation by the European Parliament (cf. the members of the European Commission). In order to circumvent the indicator of holding an elected office, which would for example also exclude the United States Secretary of State, Duke and Vanhoonacker (2006) provide indirectly a broader definition of politicians. They defined the administrative level as that of "players who are not elected or those who are not directly nominated by the European Council" (p. 164). ${ }^{3}$ Since the High Representative is nominated by the European Council, he is thus not a civil servant, which makes him automatically a politician. As definitions go, this one is however weak. Firstly, this definition suffers from 'post-hocism' in that it is explicitly geared towards the person of Solana rather than the post of High Representative itself (see also below). Secondly, such definition would also make the post of Deputy-Secretary General of the Council a political one, while the office-holder, Pierre de Boissieu is a typical bureaucrat. ${ }^{4}$

Going beyond definitions and looking at it from a political perspective, it

3 The Secretary of State is, however, subject to hearings by the United States Senate.

4 Not to mention the President of the European Central Bank, who following the German system is traditionally independent from politics! 
is worth recalling that when the member states created the position of the High Representative during the Amsterdam summit (1997), there was considerable disagreement on whether the future occupant should be a politician or a bureaucrat (Duke 2002; Cameron 2007; McDonagh 1998; Crowe 2004). France initially had its former president Valéry Giscard d'Estaing in mind when it first suggested the creation of this position in the preparation of the Intergovernmental Conference (Moravcsik and Nicolaides 1999). The United Kingdom, on the other hand, thought of a bureaucratic figure, such as Lord David Hannay (Missiroli 2004). Germany for its part took an integrationist point of view and suggested embedding in the existing institutional structures. As a result of this disagreement, the final decision on the level of the High Representative was delayed until the nomination of the candidate after the entry-into-force of the Treaty in 1999. During the press conference following the Amsterdam summit, President Chirac answered in this respect, on whether he was satisfied with the new arrangements, that "it fully depends on the person who gets appointed". ${ }^{5}$ Yet given that nominations for European posts generally result in lowest common denominator agreements, due to the consensus requirement, there was no way to assume a high level nomination back in $1997 .{ }^{6}$ The intention of the Treaty was thus not to have a strong political position (see below why Javier Solana eventually got appointed).

In addition to the appointment procedure, the contents of the job, as described by the Treaty were not typical for a politician either. In fact, the formal competences of the High Representative were, for obvious reasons, extremely limited. Solana only formally assisted the Presidency and the Council "in matters coming within the scope of the [CFSP], in particular through contributing to the formulation, preparation and implementation of policy decisions, and, when appropriate and acting on behalf of the Council at the request of the Presidency, through conducting political dialogue with third parties" (article $26 \mathrm{TEU}$; also article 18(3)). In this respect, the High Representative hardly had any mandate of his own. Compared to many national constitutions, this is an extremely small role for a politician in the executive. One of the functions of national constitutions, despite all their differences, is indeed to define the mandates of the three branches of government. Yet with four references in the Amsterdam Treaty, the position was ill-defined. The Lisbon Treaty, by contrast, has 72 references to this post.

Finally, one can argue that it is about the person and not about the position, that the position is irrelevant and that the incumbent gives the position content. While such actor-oriented perspective would defy much of the institutionalist academic literature to this date (for overviews, see Hall and Taylor 1996; Peters 1999), it also fits uncomfortably with empirical studies in the context of the European Union. Smith (2003), for example, notes in his article on the European Commissioners that their previous background (either political or technocratic) does not automatically lead to similar behaviour as a Commissioner. Thus, the fact

5 NRC Handelsblad (18 June 1997) Hervorming instellingen doorgeschoven; Verdrag Amsterdam na moeizaam overleg.

6 The examples are abundant: Jacques Santer, Romano Prodi, José Manuel Barroso, Herman van Rompuy, Catherine Ashton were all compromise candidates. Even Jacques Delors, as a French finance minister, was initially not seen as a high level candidate. 
that Javier Solana had been the Spanish Foreign Minister and the Secretary-General of NATO was not directly relevant as to whether he would behave in any particular political manner (see Algieri and Stahl in this volume on how his background had an impact on his preferences). To conclude, the position of the High Representative under the Treaty of Amsterdam was not unambiguously political. The appointment procedure favoured a technocrat and the contents of the job was unclear. This institutional setting, as the chapter will later argue, had an effect on Solana's activities.

Javier Solana was eventually appointed as the High Representative during the Cologne European Council (3-4 June 1999). That the member states chose the serving Secretary-General of the NATO had more to do with the international context than with the fact that the United Kingdom had completely changed its mind. While the Heads of State and Government were meeting in Germany, NATO was carrying out its 'humanitarian' bombing campaign in Kosovo under the leadership of the United States (24 March-11 June). Solana's success in keeping the North Atlantic Alliance together politically was seen as a major achievement. Furthermore, he would give the European Union the profile to the outside world, which it had lacked during its various diplomatic attempts to stop the Kosovo conflict. Finally, Solana had a good relationship with the United States. It was thus the international context of Kosovo, which led member states to appoint a former politician as their High Representative.

\subsection{Council Secretariat: an administration full of politics}

Whereas the High Representative was not a typical politician, the Council Secretariat is an unusual administration. Firstly, there is no clear bureaucratic hierarchy. In addition to the basic Directorate-General for External Relations (DG E), there are various bureaucratic bodies floating around within the Secretariat. Most of these are directly attached to the office of the High Representative and 'under his authority' (Duke in this volume). While the EU Military Staff (EUMS) is formally a Directorate-General, for example, it is not mentioned in the official organigram amongst the other 'normal' DGs of the Council Secretariat. The same goes for the oddly-named Civilian Planning and Conduct Capability (CPCC), which is the civilian variant of the EUMS and the Operational Headquarters. The Policy Unit is also directly attached to the private office, but halfway Solana's term-in-office the decision was made to merge parts of the Policy Unit with DG E. Within the Policy Unit, the member states created the Joint Situation Centre (SITCEN), which also directly reported to Solana. In contrast, the civilian and military planning directorates (DG E VIII and DG E IX) are part of the normal Directorates-General structure. Given all the bureaucratic developments within the Council Secretariat and the unclear hierarchy between all these bodies, one can hardly speak of a stable administration with clear leadership at the top.

Another feature of the Council Secretariat is the extreme variation in the appointment procedures and the backgrounds of the civil servants (Juncos and Pomorska 2010). Within the Council Secretariat, there are firstly permanent civil servants, who have passed the European Union concours and who are enjoying a 
life-time appointment. Some of them are working in the external relations services and the private office of the High Representative. Secondly, there are the officials of the Policy Unit, who are paid for by the Secretariat, but sent by the member states. They stay within the Secretariat only for three to four years. Thirdly, there are the 'properly' seconded national officials in DG E, who are sent and paid for by their member states. They are there for a temporary basis as well and receive an per diem from the Secretariat. Fourthly, there are seconded national officials, which are paid for by the Council Secretariat, because seconded national officials are not allowed to negotiate with third parties on behalf of the Secretariat. They are, however, also on a temporary contract. Finally, there are the national military officers, who have been seconded to the EU Military Staff and who occupy a particular seat, which has been allocated to the member states in a system that ensures geographical balance. Thus the status of the staff in the Council Secretariat varies widely from permanent civil servants to national seats and there is a lot of turnover - particularly in ESDP - as a result of the temporary nature of the contracts.

The same can be said about the educational and professional backgrounds of these civil servants, which often vary accordingly. The permanent officials of the Council Secretariat are often trained as generalists with a strong European Union expertise and knowledge. Many of the seconded national officials, by contrast, come from the foreign (or line) ministries of the member states and thus have a background as diplomat with often postings abroad (though mainly Europe) (Juncos and Pomorska 2010). The military officers are always seconded by the national defence ministries and have often very limited experience and affiliation with the European Union. This is simply for the reason that European Security and Defence Policy is a new phenomenon and that it is for most member states not of primary military importance (cf. NATO). The Weberian / Monnet civil servant did not exist in the foreign policy services of Council Secretariat.

Another interesting finding of Juncos and Pomorska (2010) is that tasks and role perceptions of individual civil servants in the Council Secretariat strongly correlate with their background and their recruitment procedure. National seconded officials, who are generally recruited because of their specific expertise, which the Secretariat does not possess, report that their main tasks indeed include the provision of information, expertise and analysis. The more traditional civil servants, who entered the Secretariat via the concours, saw administrative support and support for the Presidency as significantly more important than their seconded counterparts. Such differences in objectives and perceptions of function is quite different from national administrations. Furthermore, none of the staff members has particularly strong allegiances to the Council Secretariat as an institution and they do not see it as their own role to defend its territory, which has both positive and negative sides to it. This supports the idea that the organisation is fragmented and consists of separate units and pieces, which are informally linked together in a network type of sense.

\section{Political-Administration Relations on a Day-to-Day Basis}


It can thus be argued that the High Representative was not a typical political position and that the Council Secretariat was not a typical Weberian bureaucracy. While this certainly poses challenges to the usefulness of studying the politicsadministration relations (and should probably lead to a reconsideration of the dichotomy), it is probably more constructive to analyse the implications for the relationship between Solana and his civil servants in practice. The remainder of this chapter looks at how the limits of the political office of the High Representative and the instability and lack of continuity in the administration structured their relations. It firstly discusses the division of labour between the political and administrative level, then the direct contacts of Solana with civil servants and finally it looks at Solana's role as regards organisational leadership over the development of the Council Secretariat.

\subsection{Javier Solana's Activities and Priorities}

Since the position of the High Representative was not unambiguously political, Solana went to great length of establishing his political profile (e.g. Crowe 2003; interview with Council Secretariat officials in Brussels 2007, 2009). One of the ways was to try to keep any activity of a bureaucratic nature off his agenda. The first important thing, in this respect, which came up, was the permanent chairmanship of the newly created Political and Security Committee (PSC) (see also Regelsberger in this volume). While some member states expressed their preference for the High Representative to be the permanent chair of this committee (see Duke 2005; Juncos and Reynolds 2007), Solana was privately happy that he was not delegated this task (interview with Council Secretariat official in Brussels, 2009). It would have bound him to ambassador gatherings in Brussels twice per week. The fact that the member states eventually abandoned the idea of a permanent chair and that they opted for a rotating chair, allowed Solana much more flexibility to travel over the world and to be the face of the European Union outside Europe.

That Solana wanted to deal with the 'big picture' is clear when looking at his activities in the Middle-East Peace Process, in the Iranian non-proliferation dossier, in the Western Balkans and during his mediation activities in the Former Yugoslav Republic of Macedonia, Ukraine, Lebanon and Georgia. Occupying the EU seat in the Middle-East Quartet was, in particular, quite a stunning move given the highly politicised nature of the dossier, the different preferences of the member states and the level of his interlocutors. Yet it is also worth noting that Solana only entered the conference table at the Sharm El Sheikh summit (17 October 2000) with the likes of President Clinton, Secretary-General Annan, President Mubarak and the King of Jordan, after his presence was requested by Clinton, Annan and Mubarak. In other words, he was not explicitly sent by the member states or the Presidency, although President Chirac (the Presidency-in-office) did let it happen and staffed him with his political director. It is furthermore necessary to state that this was his first major appearance on the international scene as the EU High Representative and that it had taken exactly 365 days since he entered office on 18 October the year before. 
Nonetheless, his presence at Sharm El Sheikh was an important stepping stone for the first Quartet 'meeting' in New York, which took place in the margins of the United Nations General Assembly (November 2001). Secretary-General Annan invited Solana rather than the Belgian Presidency-in-office, together with Colin Powell, the Russian Foreign Minister Sergei Ivanov and the Israeli and Palestinian delegations to discuss the Middle-East Peace process. After the 9/11 attacks, the focus of the International Community had shifted to Afghanistan and this was an attempt by the UN Secretary-General to put the Middle-East peace process back on the agenda. A couple of months later (April 2002), the Spanish Presidency-in-office decided to host a meeting in Madrid with Powell and Ivanov coincidentally passing through the Spanish capital at the same time. This was when the Quartet was officially founded. This case makes clear that third parties preferred to deal with Solana, as the continuous representative from the European Union, than with the ever rotating Presidencies, which they often barely knew. Yet he was only invited because of his personal network, not because he was the formal European Union High Representative (interview with Council Secretariat official in Brussels, 2009).

The extraordinary amount of preparatory work, which Solana spent on his maintenance and creation of international networks counts for many of the other dossiers as well. Particularly in the Western Balkans, Solana was visiting countries, where other national foreign ministers had long lost their interest. It is, in this respect, not a coincidence that his first official trip was to Kosovo after he assumed office (interview with Council Secretariat official in Brussels, 2009). As a result, he was eventually in the position to mediate during the conflict in the Former Yugoslav Republic of Macedonia (FYROM, 2001) - together with the NATO Secretary-General - and with respect to the relationship between Serbia and Montenegro (see Stahl in this volume). Similarly, when a war broke out between Israel and Lebanon in 2006, Solana personally knew the actors (the Lebanese Prime Minister Siniora had become even one of his friends) and was capable of limiting the damage. The point regarding these regional activities is thus that while Solana indeed at moments played an important political role, he could only do this, because of the groundwork he had laid earlier, which had resulted in valuable networks and a detailed knowledge of the state-of-play. Stahl (in this volume) points, in this regard, to the tremendous amount of visits, he made to the Western Balkans, which was incomparable with any national foreign minister.

A similar thing can be said about his thematic activities. Again Javier Solana spend most of his time pursuing big projects, such as the European Security Strategy (ESS), the further development of the European Security and Defence Policy (ESDP) through many crisis management operations and the drive to increase military capabilities. The European Security Strategy is particularly significant, because it was not a 'second pillar document', but indeed an overarching foreign policy strategy. This shows that he was not too interested in the institutional boundaries of his function and the difference between Council and Commission turf (see also Allen in this volume). Furthermore, he was able to overcome the substantial differences between the member states at the time in the wake of the Iraq invasion by stressing what they had in common. While the initial idea to have 
a European Security Strategy came from the big three member states and while the content was much a codification of established practices, Biscop (in this volume) has pointed out that Solana and his senior advisors were very important in terms of the process through which this document came about. The European Security Strategy is therefore rightly seen as one of Solana's most important contributions to European foreign policy.

Similarly while ESDP was initiated by France and the United Kingdom in St. Malo (1998), Solana at various moments made significant contributions to its development. In particular, the proliferation of the large number of operations in the early days can be contributed to/blamed on him and his natural ally - France. After the first civilian police mission in Bosnia was launched, Solana strongly pushed for the European Union to take over NATO operations in the Western Balkans in order to establish the first military operations Concordia and ALTHEA under Berlin Plus. Similarly, he was supportive of the French idea to 'Europeanise' operation Artemis in the Congo, after the request of the United Nations Secretary-General, and to create modest operations in Georgia, Iraq and the Palestinian Territories (see Major in this volume). Finally, through his close contacts with President Ahtisaari, the European Union ended up monitoring a peace agreement between the Indonesian government and the Free Aceh Rebels (see for the individual missions, Merlingen and Ostrauskaite 2008; Grevi, Helly and Keohane 2009). Solana thought that ESDP was a useful and necessary instrument for the European Union to make a real impact on the ground and he got it eventually running.

Solana's role had not only to do with the development of ESDP as an instrument, but also with its implementation. One typical example is the ALTHEA military operation in Bosnia. With the European Union taking over this operation from NATO, Solana thought that it was a good opportunity to use the new-gained military leverage to send a clear political signal to the local Bosnian politicians. He wanted this operation to be "new and distinct" with specific focus on the fight against organised crime (e.g. Leakey 2006; interviews in Brussels, 2009). This was in his analysis the one main barrier blocking Bosnia from further progress. He furthermore wanted to strengthen the coordinating role of the European Union's Special Representatives so that both the European Union and all the international actors would work better together on the ground. While Solana did not entirely get what he wanted - due to the opposition of the Commission and the member states it illustrates the sort of things he was interested in. For Solana, the military mission ALTHEA per se was not overly relevant - NATO had done a fine job at creating a safe and secure environment - but rather the political leverage resulting from the operation, which could be used to put Bosnia further on the road to Europe (ibid.).

Civilian and military capabilities were another focal point for Solana. In order to carry out all these operations, the member states would have to make more efficient use of their military and civilian resources. Solana felt that they were not getting enough operational capabilities for what they paid annually (approximately half of the military budget of the United States). Through endless capability conferences and eventually the establishment of the European Defence Agency, which was headed by Solana himself, the member states tried to identify their shortfalls and to do something about them. It needs to be said that the result of all 
these efforts was rather modest apart from the fact that such issues were now under discussion. Capabilities were, however, not only about the number of helicopters and the efficiency of spending. There was a more political implication. One of the reasons why the United Kingdom had signed up for the European Security and Defence Policy in the first place was that it saw it as a potential capabilities-driver. By reaching results in this regard, the United Kingdom could potentially be kept on board. Thus, Solana spent considerable time on this.

Yet despite Solana looking after the big picture in the thematic dossiers, again it must be stressed that while he was not micro-managing, he was (too often) involved in the details of ESDP operations. This was partially structure-related for two reasons. Firstly, the European Union is built on legal bases, which can only be adopted by the Council of Ministers. Of particular relevance is the Joint Action without which ESDP operations cannot be (pre-)financed. Thus contrary to NATO, every single planning document has to go through the Council, which implies that technical details reach the political level and that Solana had to be able to brief the foreign ministers. Secondly, the force generation process is an important moment in the ESDP planning process and comes rather late. This means that after the member states have decided to go somewhere, Solana and his staff still have to find the necessary capabilities before the operation can be launched. Since there are almost always shortfalls, Solana often ends up calling reluctant defence ministers to ask for their contributions. In case of the EUFOR Congo operation (2006), he had to beg for one doctor, which none of the member states wanted to deliver, and which was eventually sent by Switzerland. In case of EUFOR Tchad/RCA, he had to call several times President Putin to ask for helicopters. Instead, he probably should have been be discussing more pressing concerns.

\subsection{Contacts with his civil servants}

As a result of his relentless travelling (a total of four million kilometres according to El Mundo) and his many EU meetings, the contacts of Solana with his lower level civil servants were minimal. ${ }^{7}$ Based on 46 interviews with Council Secretariat officials, Juncos and Pomorska (2010) reported the average number of direct contacts with Solana to be "less than once per month". Given that the sample also included a number of civil servants in the private office and the Policy Unit, who had more than average access to Solana, the number of contacts between the standard desk officer and Solana was likely to be close to zero. Interviewees of the Council Secretariat $(2007,2009)$ indeed confirmed that most of the business went through the Private Office, which had a major task in handling his agenda and briefings. Selected officials from the Policy Unit sometimes went on trips with Solana, were party to phone conversations, and thus had more access. While these findings are not atypical compared to national administrations, these limited number of contacts do point at quite a strong dichotomy between the lower bureaucratic level and the principal at the top.

The Weberian hierarchy was, however, not completely respected by Solana

7 El Mundo (1 December 2009) Tras una década, adiós a Solana: 4 millones de kilómetros de diplomacia. 
himself. His pragmatism and preference for personal informal relations with a number of top civil servants determined to a large extent the outcomes of his policy. It is impossible to discuss all his advisors here, but it is important to note that his relations with the Deputy Secretary-General of the Council, Pierre de Boissieu were far from ideal. Since de Boissieu was in charge of the administration of the Council Secretariat and many of the first pillar dossiers, this regularly led to problems. The Director-General for External Relations, Robert Cooper, on the other hand, was since 2003 probably one of the closest aids of Solana and worked extensively on the European Security Strategy. The same goes for the Director of the Policy Unit until 2005, Christoph Heusgen, who was one of Solana's main strategic advisors. In a different way, Solana trusted the Deputy-Director General External Relations, Pieter Feith, whom he brought from NATO and who was one of these civil servants in Brussels capable of getting the job done. However, with the Aceh mission, Feith left, only to return and to take off directly to Kosovo for the more ambitious position of double-hatted International Civilian Representative / EU Special Representative.

Other trusted people included notably his spokesperson, Cristina Gallach, who was already with him at NATO, and who did a remarkable job establishing his political profile in the media. During the beginning of Solana's first term, the Director-General for External Relations, Sir Brian Crowe, played an important role, although he was more of a traditional Council Secretariat civil servant, who had played a leadership role since the beginning of the 1990s. At a later stage (since February 2007), the Director-General of the EU Military Staff, Lieutenant-General David Leakey, became an influential military advisor. He had been the Force Commander during Operation ALTHEA, where he had tried to implement that "new and distinct" guidelines of Solana in a rather innovative way (Leakey 2006). On the ground in third countries, there were other people, such as Paddy Ashdown, the European Union Special Representative to Bosnia, who had direct access to Solana. The main point, however, is that these relations were based on personal contacts, which went all the way back to Solana's time at NATO or which he had picked up along the way. While all these people were capable of getting the job done and were by and large thinking outside institutional boundaries - particularly the pillar boundaries - their access to the political level was not based on the office they were holding, to use Weberian terms. This is not necessarily a bad thing, because these informal networks often led to effectiveness. Yet now that Solana the pivotal person in the network - has left, it is a question what of the network remains.

\subsection{Limited organisational leadership}

Considering all his relentless efforts to put European foreign policy on the map, one of the areas where Javier Solana spent little political capital was in the development of his own organisation. One official (interview 2007) noted that "while Javier Solana has many great gifts, administration and finance are not among them". He simply assumed that these things would be taken care of. Despite the significant increases in staff numbers, stated in the introduction (and in Duke in this volume), 
little organisational strategy was developed over the ten years and reorganisations followed one after another. Many of such issues cannot directly be blamed on Solana and his staff, as following article 207 of the Treaty Establishing the European Communities (TEC) the Council is responsible for the organisation of the Secretariat (and member states have continuously meddled in its affairs), yet the point is that he probably could have assumed a stronger leadership role in this regard. Issues that point to the weak organisational development of the Council Secretariat are, in particular, the very late arrival of civilian crisis management structures, the coordination of civil-military crisis management, the non-debate over an Operational Headquarters, the relationship between DG E and the Policy Unit, and the proliferation of EU Special and Personal Representatives.

The first issue is clearly the late arrival of civilian crisis management structures. It was not until 2007 that the Civilian Planning and Conduct Capability (CPCC) - some call it the Civilian Operational Headquarters (Norheim-Martinsen 2010) - was created. This was late by all standards. While ESDP was indeed initially conceived for military crisis management and capabilities, it is worth recalling that already at Helsinki European Council (1999) reference was made to "a non-military crisis management mechanism ... in parallel with the military ones" (Presidency Conclusions, article 28). In addition, most of the early ESDP operations were civilian operations, while the military operations - apart from the French-led Artemis - were conducted through NATO structures. In other words, there was an early need for civilian rather than military structures and they were not there. Only when the ambitious executive civilian mission in Kosovo arrived at the horizon, the CPCC was created, as the member states could no longer bear the risks of failure as a result of a non-professional supporting structure (interviews national and Council Secretariat officials, 2007). One national interviewee (Brussels, 2010) even states that the whole structure of civilian crisis management was probably conceived around the Kosovo EULEX operation. That it was not a priority for the Council Secretariat and Solana is a lost opportunity.

One of the anecdotes surrounding the planning of the Kosovo mission was that in the spring of 2006 (thus long before the Ahtisaari report), the Civilian Crisis Management Directorate of the Council Secretariat was so understaffed that it had to search for innovative solutions to gain more desk officers. One way of doing this was through the CFSP budget managed by the European Commission. The CFSP budget, however, could only be used for operational expenditure in third countries and not for the salaries of desk officers in Brussels. Thus, the Council Secretariat decided instead to suggest a very large Planning Team in Kosovo on the ground (interview with Council Secretariat official in Brussels, 2010). This planning team, consisting of a few dozen of staff members, effectively did all the planning from Pristina, since there was no money to pay for staff in Brussels. Apart from the fact that this solution was in the end very expensive, ad hoc and inefficient, it shows the problems that civilian crisis management had to deal with. Professional structures could have been thought out and proposed at a much more earlier stage.

Another related issue, which never really took off, was the integration of civil-military crisis management, supposedly one of the European Union's unique selling points unavailable to other international organisations. From the beginning 
civilian and military crisis management were conceptualised as distinct and compartmentalised as such. Probably one of the most typical examples was the lack of cooperation - and even outright turf wars - between EU Police Mission in Bosnia-Herzegovina and Operation ALTHEA. Both had the fight against organised crime in their mandates, but rather than to cooperate, they were defending their territories to the extent that the contract of the Head of the Police Mission was not prolonged and that the military operation was downsized (interviews Council Secretariat and Commission officials 2009). Then there was civil-civil cooperation between the second and first pillar. Again this was more often complicated than not. If the Commission and Council were not in confrontation with each other, they often ignored the other party and did things in parallel. It was not until the civilian Aceh Monitoring Mission (2005-2006) and the military EUFOR Tchad/RCA operation (2007-2009) that the relationship between the Commission and the Council improved.

Various institutional coordination mechanisms were created in Brussels to do something about this situation. Firstly, there was the much mentioned civilmilitary cell, which was created in the EU Military Staff (2004) as a result of a bad political compromise to settle difference between the Europeanist and Atlanticist orientated member states about the necessity of an Operational Headquarters (OHQ). Despite its publicity, the civil-military cell only played a role during the operations in Aceh and Sudan (Norheim-Martinsen 2010). So from an operational standpoint, its usefulness is in doubt. This had partially to do with its military bias, but also with the fact that there was not enough political will among the member states for real civil-military operations. A second invention in order to improve civil-military cooperation were the Crisis Response Coordination Teams (CRCTs) made up of representatives from the various bodies in the Council Secretariat and the Commission, which generally meet throughout the planning phase of an operation. Its record is mixed. While in the beginning, there was limited coordination with the European Commission, Commission civil servants (interviews 2009) have expressed that it was a strong mechanism for EUFOR Tchad/RCA. Experiences are similar in the case of the weekly Kosovo Coordination Meeting in Brussels.

The long discussion over whether the European Union should have an autonomous Operational Headquarters or not, however, continued after the creation of the civil-military cell. During the fall of 2006 and the spring of 2007, substantial resources were used to create an Operational Cell within the Council Secretariat that could be activated on an ad hoc basis. Despite various exercises, it very soon became obvious that this Cell would not be used. Instead member states (i.e. the United Kingdom) would make their own headquarters available, if there was any need. This is exactly what happened in the ATALANTA piracy operation, where the United Kingdom eventually volunteered its Operational Headquarters. Nonetheless, the Operational Cell still is on standby and occupies valuable office space in the Council Secretariat building. A decision not to go for such a halfway house could have saved a lot of discussion in the Council bodies, a lot of the resources, which the European Union Military Staff put in there, as well as the resources spent on all the exercises. Solana let these things spin out of control. 
Two mergers have furthermore been on the agenda for a long time. From 2004-onwards, parts of the Policy Unit were integrated into DG E. It was felt that there was duplication between the work of both bodies, particularly in fields where DG E had a political and non-secretarial role. Yet the Policy Unit was in the Treaties, which meant that it could not be abolished and a more recent director, Helga Schmidt, has tried to play a more activist role, putting the Policy Unit back on the radar screens. Another issue was the long-awaited merger of DGE VIII and DGE IX, which became - together with parts of the EUMS - the Crisis Management and Planning Directorate (CMPD) in order to streamline the early planning of operations. One of the functional ideas was to merge the civilian and military expertise of both Directorates, yet a number of member states, notably France, saw it as an opportunity to create a stronger planning capability within the Council Secretariat. Difficult personal relations also played a role in both mergers, as the informal relations at the top were often replicated at a lower level. Some people in both crisis management directorates were difficult to coordinate.

Finally, another oddity of the Council Secretariat during Solana's time was the proliferation of EU Special and Personal Representatives. The advantage of these posts was that they brought with them supporting staff members (seconded and paid for by the member states), which reinforced the heavily understaffed Secretariat. Furthermore, the Special Representatives gave Solana a channel to influence the situation on the ground in many conflict regions (see Adebahr in this volume). Since he did not have direct access to the Heads of Commission Delegations, this was very useful. Similarly, the various Personal Representatives from counterterrorism to non-proliferation and parliament relations - served their purposes and strengthened the capacity of the Council Secretariat. That having been said, it was not an optimal situation with eleven Special Representatives flying around the globe on top of the Commission Heads of Delegation. One of the points Baroness Ashton made during her parliamentary hearings was that she would cut back on the number of EUSRs.

To conclude, one can say that the Council Secretariat under Solana was not an extremely stable organisation with a clear strategy on its own development. Civilian crisis management structures arrived too late, civil-military coordination never took really off (despite it being a selling point), discussions were instead about the possibility of an Operational Headquarters, the various mergers brought instability, and the role of the Special and Personal Representatives was not always clear. It has been stressed that this cannot solely be blamed on Solana himself, as it was often the member states that meddled in the Secretariat's affairs, but a bit more organisational leadership would probably have helped things.

\section{Conclusion: Towards Mature Political-Administrative Relations?}

This chapter has discussed the political-administrative relations between Solana and his civil servants. It has noted that their relationship was atypical compared to national administrations in that the position of Solana was not strictly political and that the Council Secretariat was somewhat different from traditional administrations. It has also discussed political-administrative relations on a more 
everyday basis. It has described that while Solana's emphasis was on big picture projects and political guidelines, he had to put great efforts into building his own personal network and profile. He was invited to many important gatherings on that basis and not as a result of the weight of his office. Furthermore, Solana was sometimes dragged into technical issues, which required his attention. In his daily contacts with his civil servants he preferred to rely on a small number of close trustees, whom he knew would get the job done. These informal relations created flexibility and often results. The drawback was that as an organisation the Council Secretariat did not always develop professionally. Solana could have played a bigger role in this respect.

This analysis also tell us something about the influence of civil servants in the Council Secretariat during Solana's term and the (lack of) their accountability. Many important decisions - particularly in the field of ESDP - were taken on a bureaucratic level often in direct consultation with the member states capitals, over which Solana had little control. One of the prominent examples, in this regard, is the direct link between France and the French seconded national officials in the military planning directorate (DG E VIII), which was extensively exploited during the planning of the EUFOR Tchad/RCA operation. With Javier Solana being only limited accountable to the national foreign ministers and the rotating Presidency, the lack of political oversight over his civil servants was worrying. Solana himself was unlikely to get involved into the details of ESDP operations, yet a clearer hierarchy and less ambiguous relations between the political and administrative level could have helped things.

The Lisbon Treaty entered into force in December 2009 and with it Solana's successor, Baroness Ashton took office. The Lisbon Treaty will change political-administrative relations in a rather fundamental way. Firstly, the position is of a much more political nature than the position of the Amsterdam Treaty. It became part of the College of Commissioners and as such Baroness Ashton although never publicly elected in her life - had to participate in the European Parliament hearings (see also Rüger in this volume). For these hearings, the services of the Commission and Council Secretariat prepared approximately 200 briefings, of which 150 deal with bilateral relations (interview Commission official 2010). This shows, apart from the magnitude of the job, also the impossible agenda that the new High Representative will be faced with. Solana did not have to bother about issues as trivial as the Presidency of Honduras, while this was exactly one of the questions during Ashton's first hearing. Given that as Commissioner, she will be expected at many Association Councils with third countries, and that as High Representative she will have to prepare and chair at least eleven External Relations Councils, her agenda will fill up quickly.

With the High Representative's position mentioned 72 times in the Lisbon Treaty it is overly codified and this gives her a much clearer description of her job than her predecessor had. What is lacking in the Treaty, however, is a description of her position vis-à-vis other members of the College, including the President and the other external relations Commissioners, and the newly created position of the President of the European Council. These relationships will be defined over time and it is not unlikely that given her overloaded agenda, various functions will be 
taken over by the President of the Commission (e.g. high-level diplomacy), by the fellow Commissioners or high-level civil servants, such as the EU Special Representatives. One of the issues, which in this respect was also raised by various civil servants, is their likely lack of access to Baroness Ashton. A very senior official (interview 2009) noted that he had contact with Solana approximately once per week, but that he was afraid that his number of contacts would strongly decrease under the Lisbon Treaty. Turning the argument around, the potential lack of contact will also give the new High Representative less control over her bureaucrats. She will be less involved and will have less expertise on all dossiers. Accountability issues thus remain a problem, something which the European Parliament also alluded to.

Whereas the High Representative's position has thus become more political, the administrative structures in the European External Action Service have more features of a typical bureaucracy compared to the Council Secretariat (see also Cameron in this volume). While the final structure of the External Action Service still has to be negotiated, and while it most definitely will contain many seconded national officials, it increasingly looks like the External Action Service is going to be a stable, hierarchical and better organised bureaucracy with Commission-like personnel and financial regulations. Like many national foreign ministries, it will have horizontal and regional directorates. There are nonetheless still a number of outstanding questions mainly relating to the relationship between the EEAS and the external relations services of the European Commission. This will definitely lead to new coordination challenges. Yet political-administrative relations seem to become more stable with the EEAS, despite its formal status as a sui generis institution. 


\section{References}

Arrow, Kenneth (1985): The Economics of Agency, in: Pratt, John / Zeckhauser, Richard (eds.): Principals and Agents: The Structure of Business, Cambridge, p. 3751 .

Cameron, Fraser (2007): Introduction to European Foreign Policy, London.

Christiansen, Thomas (2002): Out of the Shadows: The General Secretariat of the Council of Ministers, in: Journal of Legislative Studies 8:4, p. 80-97.

Christiansen, Thomas / Vanhoonacker, Sophie (2008): At a critical juncture? Change and continuity in the institutional development of the Council Secretariat, in: West European Politics 31:4, p. 751-770.

Crowe, Brian (2003): A common European foreign policy after Iraq?, in: International Affairs 79:3, p. 533-546.

Crowe, Brian (2004): The significance of the new European foreign minister, in: CFSP Forum 2:4, p. 1-4.

Dijkstra, Hylke (2008): The Council Secretariat's Role in the Common Foreign and Security Policy, in: European Foreign Affairs Review 13:2, p. 149-166.

Dijkstra, Hylke (2009): Commission Versus Council Secretariat: An Analysis of Bureaucratic Rivalry in European Foreign Policy, in: European Foreign Affairs Review 14:3, p. 431-450.

Dijkstra, Hylke (2010): Explaining Variation in the Role of the EU Council Secretariat in First and Second Pillar Policy-Making, in: Journal of European Public Policy 17:4, p. 527-544.

Duke, Simon (2002): The Common Foreign and Security Policy: Significant but Modest Changes, in: Laursen, Finn (ed.): The Amsterdam Treaty: National Preference Formation, Interstate Bargaining and Outcome, Odense, p. 475-508.

Duke, Simon (2005): The Linchpin Cops: Assessing the workings and institutional relations of the Political and Security Committee, in: EIPA Working Paper 5, Maastricht.

Duke, Simon / Vanhoonacker, Sophie (2006): Administrative Governance of the CFSP: Theory and Practice, in: European Foreign Affairs Review 11:2, p. 163-182.

Grevi, Giovanni (2007): Pioneering foreign policy: The EU Special 
Representatives, in: Chaillot Paper 106. Paris.

Grevi, Giovanni / Helly, Damien / Keohane, Daniel (eds.) (2009): European Security and Defence Policy: The first 10 years (1999-2009), Paris.

Hall, Peter / Taylor, Rosemary (1996): Political Science and the Three New Institutionalisms, in: Political Studies 44:5, p. 936-957.

Hill, Christopher (2003): The Changing Politics of Foreign Policy, Basingstoke.

Juncos, Ana / Reynolds, Christopher (2007): The Political and Security Committee: Governing in the Shadows, in: European Foreign Affairs Review 12:2, p. 127-147.

Juncos, Ana / Pomorska, Karolina (2010): Euro-Diplomats: Understanding the Political Roles of the Council Secretariat, in: European Integration online Papers (EIoP) 14.

Leakey, David (2006): ESDP and Civil/ Military Cooperation: Bosnia and Herzegovina, in: Deighton, Anne with Mauer, Victor (eds.): Security Europe? Implementing the European Security Strategy, Zurich, p. 59-68.

McDonagh, Bobby (1998): Original Sin in a Brave New World: An Account of the Negotiation of The Treaty of Amsterdam, Dublin.

Merlingen, Michael / Ostrauskaite, Rasa (eds.) (2008): European Security and Defence Policy: An Implementation Perspective, London.

Missiroli, Antonio (2004): Money Matters: Financing EU Crisis Management, in : Deighton, Anne with Mauer, Victor (eds.): Security Europe? Implementing the European Security Strategy, Zurich, p. 43-54.

Moravcsik, Andrew / Nicolaides, Kalypso (1999): Explaining the Treaty of Amsterdam: Interests, Influence, Institutions, in: Journal of Common Market Studies 37:1, p. 59-85.

Norheim-Martinsen, Per (2010): Managing the Civil-Military Interface in the EU: Creating an Organisation Fit for Purpose, in: European Integration online Papers (EIoP) 14 .

Peters, Guy (1999): Institutional theory in political science: the new institutionalism, London.

Roosenbloom, David (2008): The Politics-Administration Dichotomy in U.S. Historical Context, in: Public Administration Review 68:1, p. 57-60. 
Simon, Herbert (1947): Administrative Behaviour, New York.

Smith, Andy (2003): Why European Commissioners Matter, in: Journal of Common Market Studies 41:1, p. 137-155.

Spence, David (2006): The European Commission and the Common Foreign and Security Policy, in: Spence, David with Edwards, Geoffrey (eds.): The European Commission, London.

Vanhoonacker, Sophie / Hylke Dijkstra / Heidi Maurer (2010): Understanding the Role of Bureaucracy in the European Security and Defence Policy: The State of the Art, in: European Integration online Papers (EIoP) 14.

Waldo, Dwight (1948): The administrative state: a study of the political theory of American public administration, New York.

Weber, Max ([1922] 1978): Economy and Society. An Outline of Interpretive Sociology, in: Roth, Guenther / Wittich, Claus (eds.), Berkeley.

Wilson, Woodrow (1887): The study of administration, in: Political Science Quarterly 2, p. 209-210. 